\title{
Fibrous Dysplasia in Maxilla: A Case Report
}

\section{Gaurav Gupta ${ }^{1 *}$, DK Gupta², Neelja Gupta ${ }^{2}$ and Priyanka Gupta ${ }^{3}$}

${ }^{1}$ Associate Professor in the Department of Paediatric and Preventive Dentistry in Jaipur Dental College, Senior Consultant of Wisdom Dental Clinics, Jaipur, Rajasthan, India ${ }^{2}$ Senior Consultant at Wisdom Dental Clinic, Jaipur, Rajasthan, India

${ }^{3}$ Senior Demonstrator in the Department of Paediatric and Preventive Dentistry in RUHS College of Dental Science, Jaipur, Rajasthan, India

*Corresponding Author: Gaurav Gupta, Associate Professor in the Department of Paediatric and Preventive Dentistry in Jaipur Dental College, Senior Consultant of Wisdom Dental Clinics, Jaipur, Rajasthan, India.
Received: July 05, 2021

Published: August 05, 2021

(C) All rights are reserved by Gaurav Gupta., et al.

\section{Abstract \\ Fibrous dysplasia is marked by replacement of normal bone by excessively proliferated fibrous connective tissue interspersed with irregular immature bony trabeculae and woven bone and osteoid. Bone development ceases in woven bone stage so matured lamellar bone cannot be formed. It is a congenital dysplastic disease of bone that may occur in a single bone or multiple bones. Here we are presenting a case report of a 36-year-old female with monostotic fibrous dysplasia in maxilla.}

Keywords: Fibrous Dysplasia; Monostotic Fibrous Dysplasia; Maxilla

\section{Introduction}

Fibrous Dysplasia is a benign disorder of bone development, progress gradually and normal bone is replaced by inordinately proliferated cellular fibrous connective tissue intermingled with irregular bone trabeculae and woven bone [1,2]. Lichtenstein in 1938 delineated the clinical spectrum and named it as Fibrous dysplasia and later in 1942 by Lichtenstein and Jaffe [3]. It is thought to develop as a result of postzygotic mutation in the GNAS 1 (Guanine nucleotide-binding protein, alpha-stimulating activity polypeptide 1) gene which codes for Gs alpha membrane associated protein in patients with fibrous dysplasia, which may result in inappropriate proliferation and differentiation of osteoblastic cells. Two forms of fibrous dysplasia have been described, Monostoticwhere one bone is involved, Polyostotic- where multiple bones are involved. Later form may occur with cutaneous and endocrine abnormalities as a part of the McCune-Albright syndrome (MAS) or the Jaffe-Lichtenstein syndrome (JLS) [4]. Polyostotic fibrous Dysplasia is uncommon and usually represent in childhood with involvement of head and neck region in 50\% cases and can involve other bones also such as femur, tibia, ribs, clavicle, lumbar and cervical spine. Exact etiology of this disease is still unrecognized $[5,6]$. Clinically it is classified as monostotic or polyostotic forms, the first being focal but poorly circumscribed fibro-osseous replacement of an area of single bone and the second form is multifocal with systemic involvement and involving several bones simultaneously [7].

The monostotic form is more prevalent and accounts for approximate $70 \%$ of all cases. Males and females are equally affected with jaw bones particularly maxilla being the most commonly affected bone [8]. Same finding is present in our case too. Onset of monostotic fibrous dysplasia usually occur during the first or second decade of life, with a diffuse painless, smoothly rounded swelling being the most apparent feature [1,2]. Polyostotic fibrous dysplasia is uncommon, and females are more affected in a ratio of 3:1. The number of bones affected may varies case to case and can involve upto $75 \%$ of the whole skeleton and almost all patients with this form present craniofacial involvement and surprisingly some cases presented with unilateral involvement of body [9]. In 
Jaffe-Lichtenstein Syndrome, multiple bone involvement is associated with brown-to-white pigmentation (café-au -lait macules).

Clinically it presents as painless slow enlargement of the involved bone. Normal appearance of a bone is altered, causing expansion of bone and facial asymmetry, pathological fracture of an extremity (when in great proportions) [10-12]. Though external appearance of covering soft tissue lesion remains normal [10-12]. Pain and paresthesia occur rarely. There is a tendency for the disease to arrest with skeletal maturation or by puberty and the patient often cannot remember when the lesion was initially started [12].

Conventional OPG, scintigraphy, magnetic resonance imaging and Computed Tomography (CT) Scans are used for further assessment of this disease $[13,15]$ although CT is considered the gold standard in evaluation of craniofacial lesions [5].

Currently, surgical intervention is generally done following active growth stage and during the period of stabilisation of disease process to minimize the chances of recurrence. Lesions that cause functional disability or aesthetic impairment are treated by osseous recontouring or osteoplasty $[5,14]$.

Our case study represent, a characteristic case of monostotic fibrous dysplasia in maxilla, with attention on its clinical, imaging, histological and treatment aspects.

\section{Case Report}

A 36-year-old female came to our clinic with the primary complain of swelling in the upper left back region of jaw. No history of systemic diseases or drug allergies was reported by patient. On intraoral examination a diffuse, bony hard, nontender swelling was found in the maxillary left region, measuring approximately $3 \times 2$ $x 1 \mathrm{~cm}$ and extending from left $2^{\text {nd }}$ premolar to $2^{\text {nd }}$ molar region (Figure 1 and 2). OPG revealed a mottled unilocular radiolucency in the affected area. CT scan images revealed that lesion was limited to lower border of sinus and did not involve sinus space (Figure 3). After which surgical excision of lesion was planned with utmost preservation of teeth. Minor bone osteoplasty along with surgical excision of affected area was done along with extraction of $2^{\text {nd }}$ molar. Excised tissue was sent for histopathological examination (Figure 4). Patient was recalled after 1 week and site was healed (Figure 5).

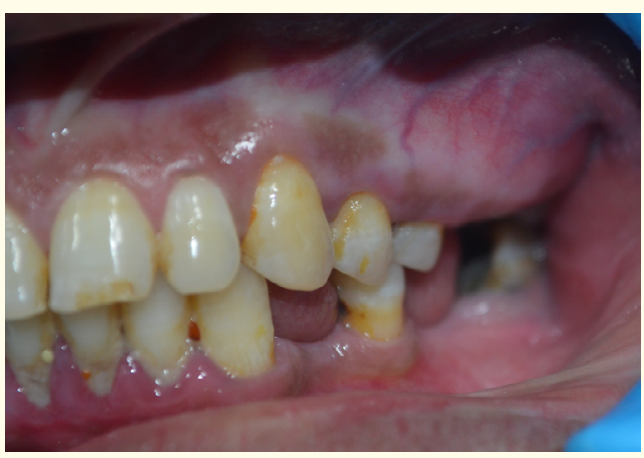

Figure 1: Facial view of lesion.

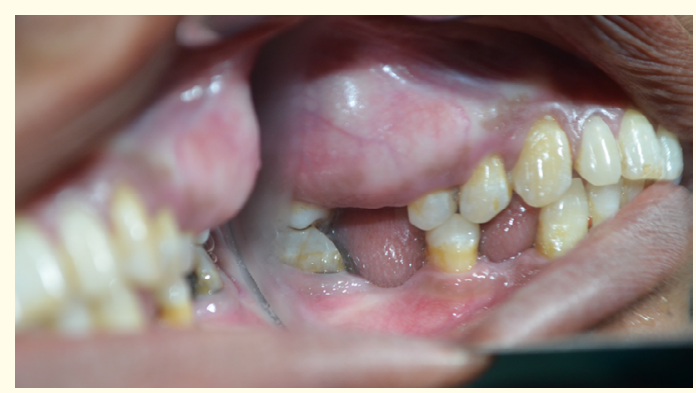

Figure 2: Mirror view of lesion.

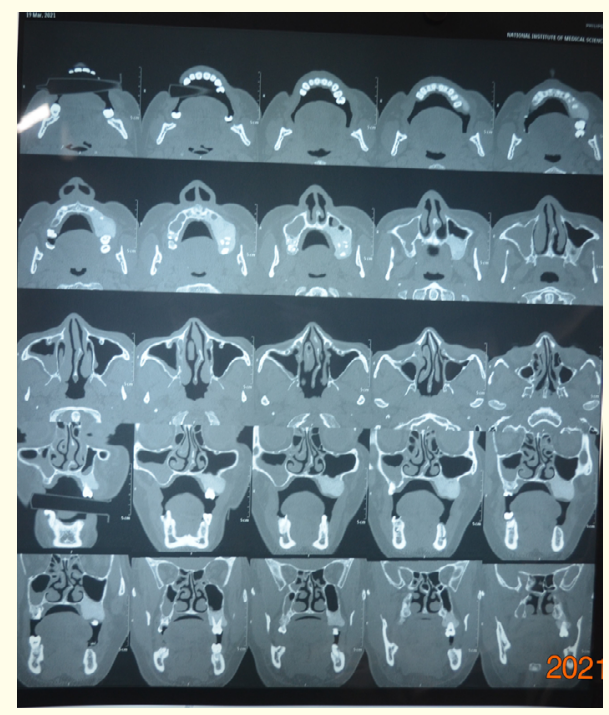

Figure 3: CT scan image. 


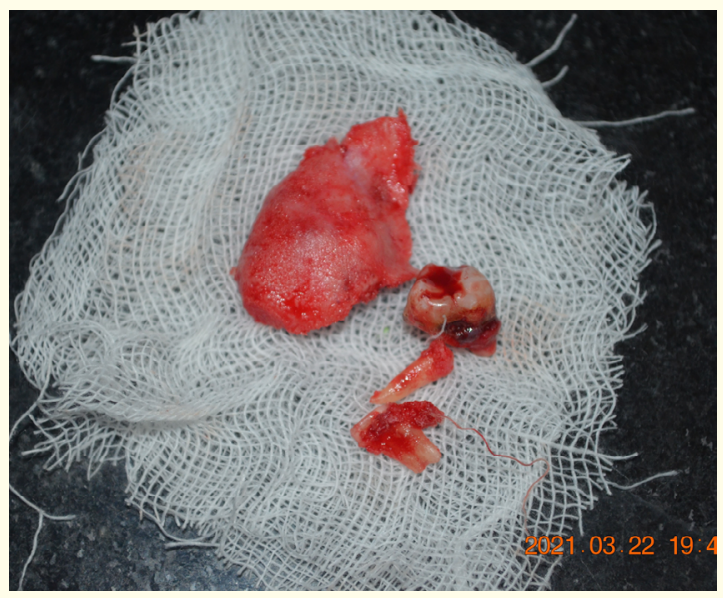

Figure 4: Excised tissue with $2^{\text {nd }}$ molar.

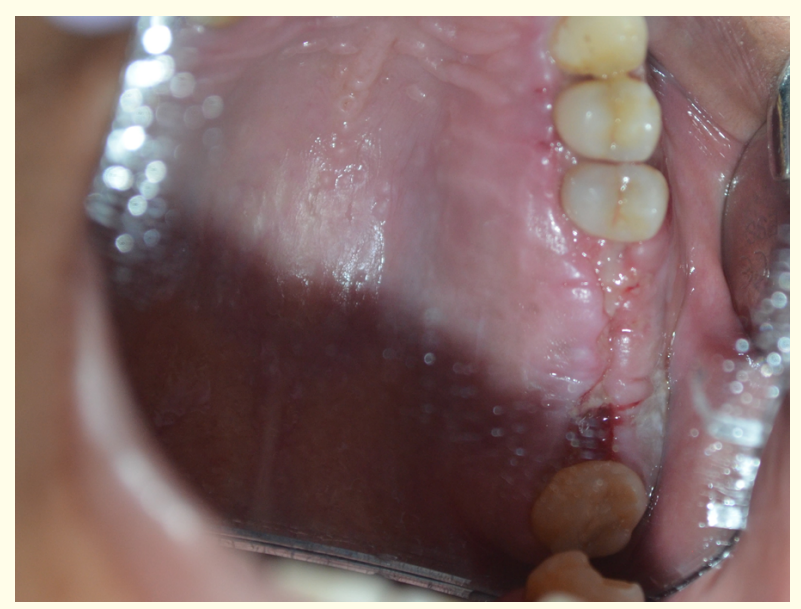

Figure 5: Follow up after 1 week.

Biopsy comprises of branching and anastomosing irregular, immature trabeculae of woven bone with presence of osteocytes and no osteoblastic rimming. The bone trabeculae are discrete, slender and accurate or branched. Some are C-shaped called Chinese trabeculae, with no definite pattern, which is suggestive of Fibrous dysplasia. Fibrous connective tissue showed cytologically bland spindle cells, with no cytologic atypia and mitotic figures (Figure $6)$. We did regular follow up of the patient for 6 months. No recurrence was reported.

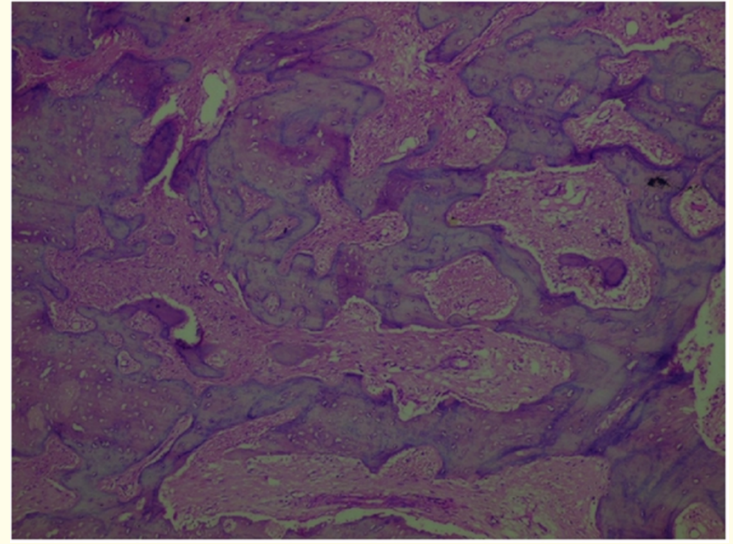

Figure 6: Histopathological image of fibrous dysplasia.

\section{Discussion}

Fibrous dysplasia (FD) is a pathology accounts for almost $2.5 \%$ of bone tumours, and approximately $7 \%$ of benign bone tumours $[16,17]$. Etiology of this rare entity is still not established by authors [12,18-20] describing various theories to explain its etiology like genetic, developmental or neurological. But now, it has been established by majority of authors that Fibrous Dysplasia occurs in scattered instances which results from a post zygomatic mutation in the GNAS1 gene which codes for Gs alpha membrane associated protein in patients with fibrous dysplasia [11]. So now we can say that FD is developmental in nature and marked by the presence of fibrous connective tissue with a characteristic whorled pattern and interspersed trabeculae of immature woven bone.

Eversole defines fibrous dysplasia as "a benign, nonneoplastic intramedullary cellular proliferation of fibroblasts, with formation of irregular trabeculae of bone that shows indistinct, nonencapsulated borders" [21]. It is a hamartomatous disorder of bone metabolism [22]. The monostotic form of fibrous dysplasia usually occurs in first or second decade of life and growth usually arrest around puberty.

The craniofacial or polyostotic form occurs in childhood, and then progresses throughout adolescence [23]. Risk of sarcomatous change is greater in polyostotic form and generally develops around early adult life. The other subtypes present with cafeaulait macular skin lesions and endocrinal disturbances, precocious 
sexual development although jaw lesion may be the most conspicuous feature.

Clinical, radiographic, and histopathological findings are mainstay of diagnosis of monostotic fibrous dysplasia [23]. Patient is usually seen with painless slow and abnormal enlargement of jaw bone with characteristic "ground-glass" appearance in OPG, and "Chinese letter" or "C shaped bone" patterns in histopathological examination $[22,24]$.

Craniofacial bones affected by FD are in the following order that is frontal $>$ sphenoid $>$ ethmoid $>$ maxilla $>$ mandible $>$ zygoma $>$ parietal $>$ occipital $>$ temporal [21].

Surgical treatment of choice in age groups of second/third decade with minor lesions are biopsy with bony osteoplasty at affected site with regular follow up for any recurrence like shown in our case also. In severe cases complete excision of lesion with bone graft reconstruction can be done [25]. Although due to diffuse, illdefined borders of lesion complete surgical excision is challenging. But clinician can always try this surgical sculpting manoeuvre to improve the patient's appearance and to provide better functional needs.

In many cases, disease tend to stabilize and essentially stops enlarging when skeletal maturation is reached, in such cases serum alkaline phosphatise and urinary hydroxyproline serum biomarkers can be used to monitor response in the nonsurgical treatment of the disease $[26,27]$. In our case the clinical features, radiographic and histopathological features were matched up to reach to a final diagnosis of monostotic fibrous dysplasia and conservative treatment was done accordingly.

\section{Conclusion}

Fibrous Dysplasia is a congenial dysplastic disease of bone which cause functional disability and aesthetic impairment and very rarely may lead to malignant transformation or pathological fractures. Radiotherapy is contraindicated because of its potential for malignant transformation. So apt clinical diagnosis and management in initial stage is of prime importance to prevent transformation to any kind of complications. The presence of an activating mutation in the gene that codes for Gs alpha membrane associated protein in patients with fibrous dysplasia, results in altered proliferation and differentiation of osteoblastic cells. Periodic follow up is necessary in young-aged monostotic fibrous dysplasia cases, due to the possibility of recurrence. We have not noticed any other development/change in our case after 6 months of surgical excision and osteoplasty of lesion and follow up is still ongoing.

\section{Bibliography}

1. Costanzi MA and Velasco e Cruz AA. "Envolvimento orbitário difuso por displasia fibrosa na síndrome de mccune albright: Relato de caso". Arquivos Brasileiros de Oftalmologia 70 (2007): 1021-1023.

2. Neville BW., et al. "Patologia Oral and Maxilofacial". $\left(2^{\text {nd }}\right.$ editionn), Rio de Janeiro: Guanabara Koogan (2004).

3. Dua N., et al. "Fibrous dysplasia of maxilla: Report of two cases". Journal of Indian Academy of Oral Medicine and Radiology 27 (2015): 472-475.

4. Agarwal M., et al. "Fibrous dysplasia: A review". TMU Journal, Dental Journal 1 (2014): 25-29.

5. Albuquerque MAP., et al. "Aspectos clínicos, patológicos e imaginológicos de um caso de displasia fibrosa". Revista da Associação Paulista de Cirurgiões Dentistas 60 (2006): 219-222.

6. Miloro M., et al. "Princípios de Cirurgia Bucomaxilofacial". (2 $2^{\text {nd }}$ edition), São Paulo: Santos (2008).

7. Simon E., et al. "Cranio-facial fibrous dysplasia in a 38-year-old African woman: A case history”. Oral Diseases 5 (1999): 247249.

8. Saueressig F and Oliveira MG. "Displasia fibrosa poliostótica associada à síndrome de Mmccune-albright: Relato de caso". Rev Bras Patology Oral 3 (2004): 70-76.

9. Botelho RA., et al. "Características tomográficas da displasia fibrosa craniofacial: Estudo retrospectivo de 14 casos". Radiologia Brasileira 39 (2006): 269-272.

10. Sentürk M., et al. "Fibrous dysplasia in the head and neck region: A report of three cases". Kulak Burun Boğaz Ihtisas Dergisi 11 (2003): 25-28.

11. Waldron CA. "Doenças do osso". In: Neville BW, Damm DD, Allen CM, Bouquot JE, Patologia oral and maxilofacial. Rio de Janeiro: Guanabara Koogan (2004): 530-542.

12. Shafer WG., et al. "Doenças dos ossos e das articulações". In: Shafer WG, Hine MK, Levy BM, Tratado de Patologia Bucal. Rio de Janeiro: Guanabara Koogan (1987). 
13. Mac Donald-Jankowski DS. "Fibro-osseous lesions of the face and jaws”. Clinical Radiology 59 (2004): 11-25.

14. Caridad JJM and Platas Jr F. "Fibrous dysplasia of the mandible: Surgical treatment with platelet-rich plasma and a corticocancellous iliac crest graft-report of a case". Oral Surgery, Oral Medicine, Oral Pathology, Oral Radiology, and Endodontology 105 (2008): 12-18.

15. Lisle DA., et al. "Imaging of craniofacial fibrous dysplasia". Journal of Medical Imaging and Radiation Oncology 52 (2008): 325-332.

16. Ricalde $\mathrm{P}$ and Horswell BB. "Craniofacial fibrous dysplasia of the fronto-orbital region: A case series and literature review". Journal of Oral and Maxillofacial Surgery 59 (2001): 157-167.

17. Alves AL., et al. "Displasia fibrosa: Relato de três casos". Revista Brasileira de Otorrinolaringologia 68 (2002): 288-292.

18. Akintoye SO., et al. "Analyses of variable panoramic radiographic characteristics of maxillo-mandibular fibrous dysplasia in Mccune-albright syndrome". Oral Diseases 10 (2004): 36-43.

19. Chen YR., et al. "Computed tomography characteristics of nonsyndromic craniofacial fibrous dysplasia”. Chang Gung Medical Journal 25 (2002): 1-8.

20. Onitsuka T and Kumagami H. "Sex hormones in fibrous dysplasia of the facial bone: An immunohistological study". Nihon Jibiinkoka Gakkai Kaiho 97 (1994): 2072-2074.

21. S Mahajan., et al. "Maxillofacial fibrous dysplasia". Indian Journal of Dental Research 16.4 (2005): 151-152.

22. BW Neville., et al. "Oral and Maxillofacial Pathology". WB Saunders, Philadelphia, Pa, USA, $2^{\text {nd }}$ edition (2002).

23. D MacDonald-Jankowski. "Fibrous dysplasia in the jaws of a Hong-Kong population: radiographic presentation and systematic review". Dentomaxillofacial Radiology 28.4 (1999): 195-202.

24. SO Akintoye., et al. "Analyses of variable panoramic radiographic characteristics of maxillomandibular fibrous dysplasia in McCune-Albright syndrome". Oral Diseases 10.1 (2004): 36-43.
25. AT Moore., et al. "Fibrous dysplasia of the orbit in childhood. Clinical features and management". Ophthalmology 92.1 (1985): 12-20.

26. H Plotkin., et al. "Effect of pamidronate treatment in children with polyostotic fibrous dysplasia of bone". Journal of Clinical Endocrinology and Metabolism 88.10 (2003): 4569-4575.

27. YR Chen., et al. "Craniofacial fibrous dysplasia: an update". Chang Gung Medical Journal 29.6 (2006): 543-549.

\section{Volume 4 Issue 9 September2021 \\ (c) All rights are reserved by Gaurav Gupta., et al.}

